\title{
A Study on The Relationship between Aggregate Impact Values (AIV) and Los Angeles Abrasion Values (LAAV) of Charnockites/Charnockitic Gneisses in Sri Lanka
}

\author{
U.de S. Jayawardena
}

\begin{abstract}
The quality of construction works in Civil Engineering largely depends on the properties of materials. The properties of rock aggregates depend upon the natural conditions of different rock types. It has been understood that the changes of engineering properties in different rock types may be related In the rock texture. Therefore studies on the engineering properties of different rock types provide prior I nowledge on the quality of such rock types as well as on potential locations of suitable sources for Industry. Aggregate Impact Values and Los Angeles Abrasion Values are the most important engineering properties of rock materials for road constructions and Charnockite/Charnockitic Gneiss is the widely distributed metamorphic rock in Sri Lanka. The objective of this research is to find out the relationship between AIV and LAAV of Charnockite/Charnockitic Gneiss in Sri Lanka.

A hundred and sixty seven (167) Charnockite/Charnockitic gneiss rock samples were collected from quarries and exposed rocks in different localities in Sri Lanka, except in the Northern and the Southern provinces, and tested for their Aggregate Impact Values and Los Angeles Abrasion Values. The results were interpreted in different ways and it was found that the ratio of LAAV/AIV for Charnockite/ 1 harnockitic Gneiss is $1.242+0.115$. The average values for AIV and LAAV of Charnockite/ $<$ harnockitic Gneiss rock are $23 \%$ and $29 \%$ respectively.
\end{abstract}

Key words: Rock aggregates, Aggregate Impact Value, Los Angeles Abrasion Value.

\section{I.Introduction}

The rocks have been classified as igneous, sedimentary and metamorphic according to their origin, texture and mineralogy. This ' lassification is not valid for engineering science be ause rock is another material. Under the civil engineering category " a rock is a hard, consolidated and load bearing material and it cannot be excavated by manual methods". I lence rocks have been classified according to their properties for engineering purposes such as tunnels, underground openings, dam foundations etc. As far as Sri Lankan rocks are soncerned, there are no (or very limited) published data to use as literature reviews. A classification of the various engineering properties of Sri Lankan rocks is therefore a necessity because it gives prior knowledge of these properties by identifying the type of rocks at any site. In order to prepare such a classification and provide more detailed literature of Sri Lankan rocks the author carried out a program of research to determine the engineering properties of those. The results of a part of this research have been published and are now available [1] for reference. It highlights the values of different engineering properties of Sri Lankan rocks and the interrelationship among them.

The suitability of aggregates should be found prior to commencing civil engineering projects. Generally crushed rocks are used for various construction projects by the contractors with or without a knowledge of their quality. Highway construction is one of those projects and crushed rocks from quarries are used for it as a major material. As mentioned earlier, different rock types process different engineering qualities.

Eng.(Dr) U.de S. Jayazvardena, BSc (Hon.) Sri Lanka, MS. AIT Bangkok, DEng Kyushu, CEng, MIE(SriLanka), Senior Iecturer in the Dipartment of Civil Engineering, University of Pernteniyn. 
The rocks of quarries which are used as highway materials in Sri Lanka belong to basically either metamorphic type or igneous type. In order to find out differences of rock properties of the crushed rocks the author carried out another program of research as a continuation of the previous research. It was mainly based on the classification of rock types in quarries for use as highway materials. The results of the research carried out by the author on the Los Angeles Abrasion Values (LAAV) of various rocks in Sri Lanka are available now [2]. Accordingly Charnockite (or Charnockitic Gneiss) is the most suitable rock type to be used in highway construction. Aggregate Impact Value (AIV) is another index parameter that can be used to measure the hardness of the rocks or crushed stones. Both these LAAV and AIV tests indicate the fracturing resistance of crushed rocks under impact loads. The objective of this research is to find out the relationship between AIV and LAAV of the best rock material, Charnockite/Charnockitic Gneiss in Sri Lanka.

\section{Charnockite Rock in Sri Lanka}

Geologically nine tenth (90\%) of Sri Lanka is made up of high grade metamorphic rocks of Precambrian age i.e., older than 570 million years, belonging to one of the ancient and stable part of the earth's crust, called the South Indian Shield. The remaining rocks are sedimentary rocks of predominantly Miocene age in the north-west (and very few places of south east) with some Jurassic sediments preserved in small faulted basins. There are recent sedimentary formations, identified as Pleistocene Deposits in a few locations. Some of the Igneous or igneous looking rocks intruding the metamorphic rocks of Sri Lanka are granites, dolerites, pegmatites, quartz veins, serpentinite and a carbonatite [3].

The Precambrian metamorphic rocks in Sri Lanka can be divided into two major groups namely Highland Complex and, Vijayan and Wanni Complex. Other smaller groups are Kadugannawa Complex, Buttala Complex, Kataragama Complex and Kuda Oya Complex (Fig.1) [3]. The common Precambrian metamorphic rocks in the country are charnockite/ charnockitic gneiss, quartzite, marble, dolomite, granulite, migmatite, gneisses (garnet sillimanite graphite gneiss, hornblende biotite gneiss, biotite gneiss, calc gneiss, cordierite gneiss, wollastonite-scapolite gneiss, granitic gneiss) and amphibolites All of these are considered as meta-sedimentary rocks[4].

It has been apparent for some years that charnockites are genetically of two kinds, namely metamorphic and igneous [5]. Metamorphic origin charnockites are generally referred to as charnockitic gneiss. The geological map of Sri Lanka indicates that one of the widely distributed rocks in this country is charnockitic gneiss and that it is one of the major rock types in the Highland Complex [6]. It also can be seen in Buttala, Kudaoya and Kataragama Complexes and some localities in Wanni and Vijayan Complex [6]. Similar to metamorphic charnockitic gneiss there is igneous origin charnockite rock along the eastern coastal belt near Panama. It is referred as hypersthene granite or in trusive charnockite [6]. For this study the author used the word "charnockite" for the selected rock without considering the genetic terms.

The most important minerals in charnockite are hypersthene and plagioclase feldspar [5]. Some charnockites are banded type and others show very uniform medium to coarse grain size mineral distribution. All are of even grain texture. Bluish or greenish grey colour surface and oily or greasy surface appearance are the most significant identifying features of charnockite in the field. Microscopic identification is important to describe the texture ofdifferentsamples.

\section{Method of Study}

\subsection{Sample Collection}

Fresh rock samples of charnockite rock were collected from exposed rocks and selected quarries which either were in operation or abandoned in Anuradhapura, Badulla, Colombo, Kalutara, Kandy, Kegalle, Kurunegala, Matale, Moneragala, Nuwara Eliya, Polonnaruwa, Ratnapura and Trincomalee administrative districts of Sri Lanka. Samples were collected by (i) the author for his individual research (ii) by the undergraduate students for their final year projects (iii) the quarry owners and/or contractors who wanted to check the quality of their quarry rocks. Table 1 indicates the total number of samples collected by each category and the number of samples collected from different districts (Fig. 2). 

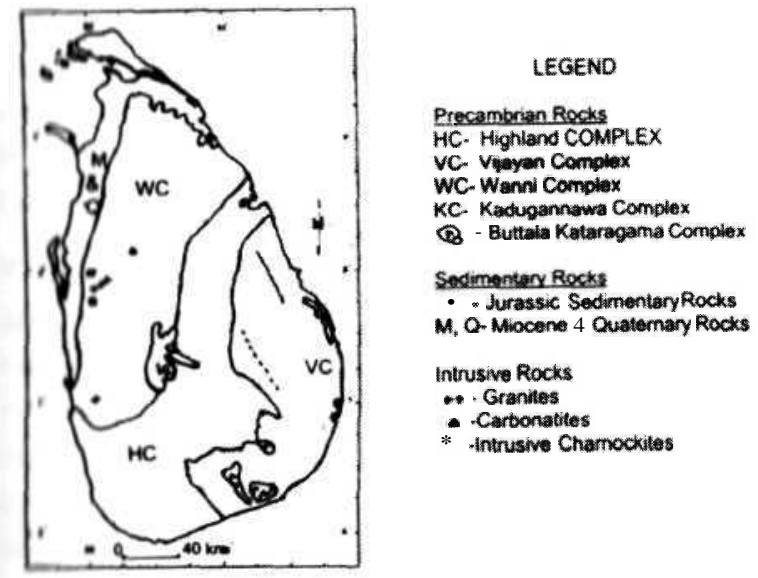

Hig.1 Geological subdivisions of Sri Lanka [3]

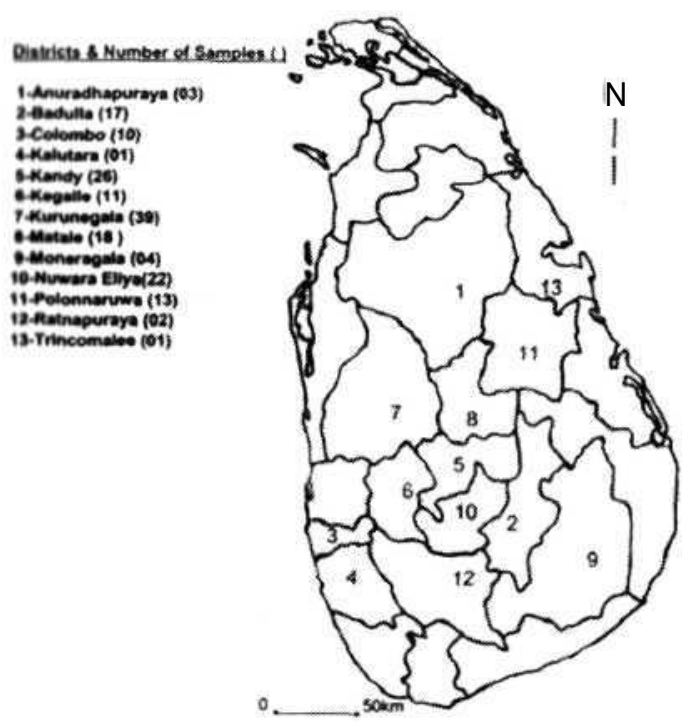

Fig. 2 Total numbers of sampling locations in different districts

\subsection{Laboratory Tests}

The apparatus called Aggregate Impact Tester was used for the AIV test. The tests were carried out according to the standard method BS812: Part3: 1975. in the Materials Laboratory of the I lepartment of Civil Engineering. Two samples from each quarry were tested.

The Los Angeles Abrasion Testing Machine for the determination of abrasion resistance of rocks was used for the test. The tests were carried out according to the standard method C131-76 ASTM [7] in the Geotechnical Laboratory of the Department of Civil Engineering. At least four days were needed to complete this experiment per sample. Therefore only one sample was taken from most of the locations for this experiment.

Table 1. Total number of sampling points.

\begin{tabular}{|l|c|}
\hline \multicolumn{1}{|c|}{$\begin{array}{c}\text { Administrative } \\
\text { District }\end{array}$} & $\begin{array}{c}\text { Number of } \\
\text { Samples } \\
\text { ( Locations) }\end{array}$ \\
\hline Anuradhapura & 03 \\
\hline Badulla & 17 \\
\hline Colombo & 10 \\
\hline Kalutara & 01 \\
\hline Kandy & 26 \\
\hline Kegalle & 11 \\
\hline Kurunegala & 39 \\
\hline Matale & 18 \\
\hline Moneragala & 04 \\
\hline Nuwara Eliya & 22 \\
\hline Ratnapura & 13 \\
\hline Pollonnaruwa & 02 \\
\hline Trincomalee & 01 \\
\hline & \\
\hline TOTAL SAMPLING POINTS & $167 * *$ \\
\hline ** No. of Samples colleted by \\
the author \\
the contractors $=45$
\end{tabular}

\section{Method of Analysis}

For this investigation 167 samples (from 167 sampling locations) were collected within 13 administrative districts in Sri Lanka. Samples could not be collected from the other districts where exposed charnockites were available [6]. For Eastern province, only one sample was collected from Kantale area. The interpretation of results was done in three ways.

\subsection{Graphical Interpretation}

Figure 3 is the variation of LAAV against AIV for charnockite rock. The test results clearly show that for one AIV there are several LAAV. 


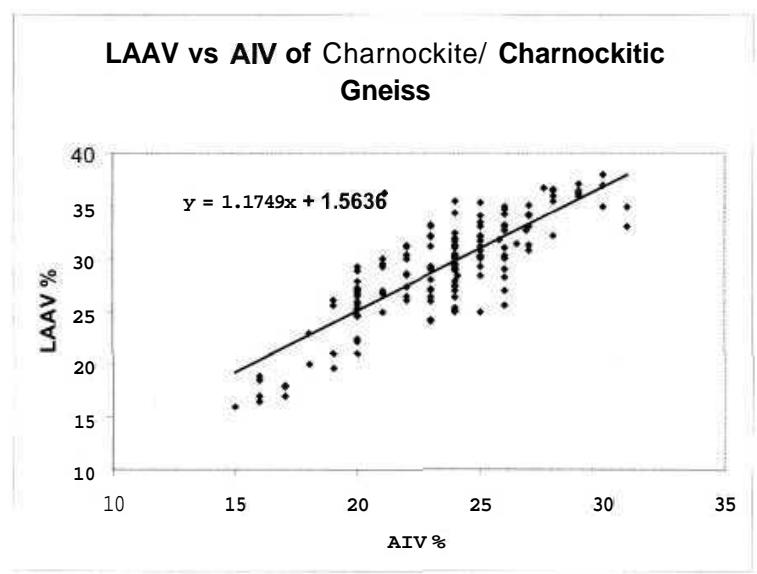

Fig. 3. Variation of LAAV vs VIA for Charnockite rock in Sri Lanka

\subsection{Statistical Analysis of Raw Data}

Simple statistical analysis was carried out for this data sample of 167. This total number of samples gives reasonable average values of AIV and LAAV for charnockite rock (Table 2).

\subsection{Statistical Analysis of The Ratio of LAAV/AIV}

The ratio of LAAV and AIV is also used to find the direct relationship between these two parameters without considering the graphical relationship. Table 3 shows the minimum and maximum ratios, average ratio and the standard deviation.

\section{Results and Discussion}

\subsection{GraphicalInterpretation}

According to Fig. 3 there are several LAAV for one AIV. The reason for this variation is not very clear but it can be assumed that the difference of sample quantity required for the tests may have created some variations in the results. For the AIV experiment about $300 \mathrm{~g}$ of crushed rock is sufficient, whereas for LAAV the weight of the sample should be $5000 \mathrm{~g}$. Therefore, possible micro level textural changes and micro cracks within the larger size sample may have changed the LAAV. Such variation cannot be observed from a smaller size sample. However the LAAV test results do not fall within a larger or scattered range. The variation shows an increase of LAAV with the increase of AIV. The correlation between these two parameters is not really linear, but for general estimation a linear relationship can be considered. Figure 3 indicates a possible relationship which can be considered as LAAV = 1.2 AIV + 1.6. This is only for charnockite rock in Sri Lanka. The reliability of this linear relationship is difficult to explain further because the constant (1.6) has no meaning.

LAAV test can be carried out for smaller size (similar to AIV) samples also [7]. In this experiment the effects of micro cracks in larger rock samples can be investigated. This test is in progress.

\subsection{Statistical Analysis of Raw Data}

Table 2 shows the results of the statistical analysis of raw data. The range of AIV varies from $15 \%$ to $31 \%$ and average is $23.4 \%$. The LAAV ranges from $17 \%$ to $38 \%$ and the average is $29 \%$. Most of the samples show the AIV is less than $26 \%$ and LAAV is less than $30 \% .15$ samples showed LAAV higher than $35 \%$.

Table 2 Experimental results.

\begin{tabular}{|l|c|c|}
\hline & AIV & LAAV \\
\hline Minimum value & $16 \%$ & $17 \%$ \\
\hline Maximum value & $31 \%$ & $38 \%$ \\
\hline Average & $23.4 \%$ & $29.1 \%$ \\
\hline Standard Deviation & 3.1 & 4.5 \\
\hline About $2 / 3^{\text {rd }}$ data range & $20.3-26.4 \%$ & $24.6 \%-33.6 \%$ \\
\hline
\end{tabular}

The extreme values either lower or higher from both tests may be due to some textural changes of the rock or the local variation of the samples and it is not advisable to say the maximum or minimum values are the values of the whole quarry area. The standard deviation of AIV is $3.1 \%$ and it is $4.5 \%$ for LAAV. It indicates that about $2 / 3$ of results for charnockite rock fall within 20-26\% for AIV and 24-34\% for LAAV. In general the permissible LAAV for bituminous surface dressing (premix carpetting) is $35 \%$ and bituminous concrete is $30 \%$ [8]. Therefore charnockite rock can be selected as a suitable highway material in Sri Lanka.

\subsection{Statistical Analysis of The Ratio of LAAV/AIV}

According to Table 3, LAAV is, on average, 1.242 times AIV. The standard deviation of 0.115 indicates that $2 / 3$ of the values lie between 1.127 
and 1.357. From this calculation method the $2 / 3$ range of LAAV may be found from one AIV. For average AIV obtained from a quarry the range of I A A V values may be obtained by this easy , iliulation.

To carry out an AIV test a smaller quantity of sample is required and it takes a shorter time for sample preparation and completion of the test. I lowever, for LAAV test the quantity required is veri large and it takes more manpower and a number of days for sample preparation and lesting.

Table 3. Ratio of LAAV to AIV

\begin{tabular}{|l|c|}
\hline & $\begin{array}{c}\text { Ratio of } \\
\text { LAAV/A1V }\end{array}$ \\
\hline Minimum value & 1.000 \\
\hline Maximum value & 1.443 \\
\hline Average & 1.242 \\
\hline Standard I leviation & 0.115 \\
\hline About 2/3 data range & $1.127-1.357$ \\
\hline
\end{tabular}

From one LAAV sample several AIV tests can be done. A better knowledge of the relationship between AIV and LAAV is very important to the construction industry especially for highway instruction. A quarry can be recommended for use as a source of coarse aggregates and base materials after several AIV tests. They provide LAAV values by applying an experimentally proved relationship between these two parameters. This paper provides a ratio between I AAV and AIV of charnockite/charnockitic gneiss, the most widely distributed rock in Sri I anka. Similar experiments are being carried iul by the author for other rock types in Sri I anka also.

\section{6, Conclusion}

The laboratory experiments carried out for AIV and LAAV of Charnockite/ Charnockitic Gneiss rock in Sri Lanka provided their range and the averages. Accordingly it is a suitable material for road construction. The recognition of the rock is enough to assume the general range of both $\checkmark$ alues prior to earring out the laboratory test.

A relationship between AIV and LAAV for Charnockite rock, the best highway material in Sri Lanka, was found by the laboratory experiments. By one interpretation this relationship can be mentioned as LAAV $=1.2 \mathrm{x}$ AIV +1.6 but there is no acceptable meaning for the intercept of this linear relationship.

By second interpretation 2/3 of LAAV values fall between $24-34 \%$. Average AIV is $23 \%$ and Average LAAV is $29 \%$.

By third method the ratio of LAAV / AIV is equal to $1.242 \pm 0.115$. This third method is more convenient and acceptable than the first two methods.

This experiment will return to study the relationship between resistance to abrasion and rock texture.

\section{References}

1. Jayawardena, U.de S., 2001, A Study on the Engineering Properties of Sri Lankan Rocks, Jour. of the Inst. of Eng., Sri Lanka, Vol xxxiv $\mathrm{p} 7-21$

2. Jayawardena, U.de S.,2004, Classification of Sri Lankan Rocks for Highway Materials, Proceeding of the Peradeniya University Research Sessions, University of Peradeniya, Peradeniya, p90.

3. Cooray, P.G., 1994, The Precambrian of Sri Lanka:A historical review, Precambrian Research, 66: 3-18.

4. Cooray, P.G., 1967, An Introduction to the Geology of Ceylon, Dept. of National Museums, Govt. Press, Colombo, p 340.

5 . Cooray, P.G., 1986, Charnockite Nomenclature, Geological Society of Sri Lanka Publication, p144.

6. The Geological Map of Sri Lanka, 1997, Geological Survey and Mines Bureau, Sri Lanka.

7. Asian Institute of Technology, 1981, Laboratory Manual for Rock Testing, Bangkok, Thailand, p205.

8. Garg, S.K., 2003, Physical and Engineering Geology, Khanna Publishers, India, p799. 